\title{
Managing Photograph Collections
}

\author{
by Molly G. Rawls
}

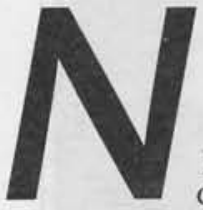

issen Park ... West End School ... Crystal Lake ... Chestnut Street Train Depot. The list of places goes on and on. Winston-Salem residents may recognize the place names from memories of growing up here or from stories passed down through families. Perhaps they rode the streetcar through Waughtown to spend a Sunday afternoon at Nissen Park, picnicking under the trees and later strolling along the paths. Nissen Park, built by the streetcar company around 1900, was strategically situated at the end of the streetcar line. For many years it was the preferred destination for Sunday School picnics, roller skating socials, dramatic performances, and for taking in the beauty of the botanical gardens. Groups of children came to the park, guarded closely by their chaperones in long dresses and wide-brimmed hats.

Long before the streetcar ended its routes in 1936, Nissen Park fell into disuse. As more residents owned automobiles, the choices of social locations expanded and were not limited to a streetcar route. Gradually Nissen Park became so overgrown that the Civilian Conservation Corps was instructed to clean it up. Finally, bulldozers filled in the ponds, scraped up the concrete walkways, pulled down the buildings, and erased all traces of the park. Today a housing development has again brought life to the area, but probably very few residents realize they are living where their ancestors once sought recreation and escape from the hurried city life.

Local researchers are able to find very little written information about the park. Most of what is known about the park has come from photographs. Fortunately for local history enthusiasts in Winston-Salem, the stories of places such as Nissen Park, as well as people, buildings, and events, live through the photographs found in the Forsyth County Public Library's Photograph Collection.

\section{Background of the Collection}

The majority of the photographs record the day-to-day life in Winston-Salem and feature the people and events of the city. Both the business and social life is reflected in the photographs which date from the late 1880 s to the mid 1970 s. The photograph collection consists of approximately 40,000 black-and-white photographs, 100,000 negatives, 1,200 copy negatives, and 200 internegatives, plus color slides and $16 \mathrm{~mm}$ movies. The bulk of the collection came from three individuals - Frank Jones, Jim Keith, and Bill East.

Frank Buxton Jones Jr. was a Winston-Salem native and a photographer for the Winston-Salem Journal from 1937 until his death in 1975 . Frank not only covered the events of the day for publication in the newspaper, but he also collected older, historical photographs of the city. During his years with the newspaper he won numerous awards for his photography, wrote columns in the newspaper on photography, and participated in photographic exhibits.

Upon Frank's death in 1975, his photographs were willed to the Wachovia Historical Society in WinstonSalem. In 1983 the Society placed them on permanent loan at the Forsyth
County Public Library. The unidentified and uncataloged collection arrived in file cabinets, photographic paper boxes, laundry carts, and cardboard boxes.

In 1992 the Library received the Jim Keith collection. Jim Keith was also a Winston-Salem Journal photographer, from 1954 to 1973 . His 3,600 photographs complement those from Frank Jones in giving a complete look at this period in the city's life. The Keith photographs arrived in 16 photographic paper boxes and were also unidentified and uncataloged.

Bill East was a reporter and later an editor for the Twin-City Sentinel. For several years he wrote a regular newspaper feature entitled "Do You Remember?" which focused on a photograph and gave the historical significance of the building, person, or event featured in the photograph. The 750 photographs that comprised his collection offered an invaluable view of the city from the 1870 s to the 1930 s. Shortly before his death in 1992, Bill East requested that his collection be given to the library. It also arrived uncataloged, undated, and unidentified, but in plastic sleeves arranged in binders.

When the Frank Jones collection arrived at the library in 1983, library administration knew that organizing the voluminous and historically significant collection would be an arduous task. Not only was the size overwhelming, but also over the years the collection had been handled, pulled from, and rearranged so that the original order was badly disturbed. Over 14,000 photographs were removed from the boxes and placed in file cabinets under broad subject categories (such as Down- 


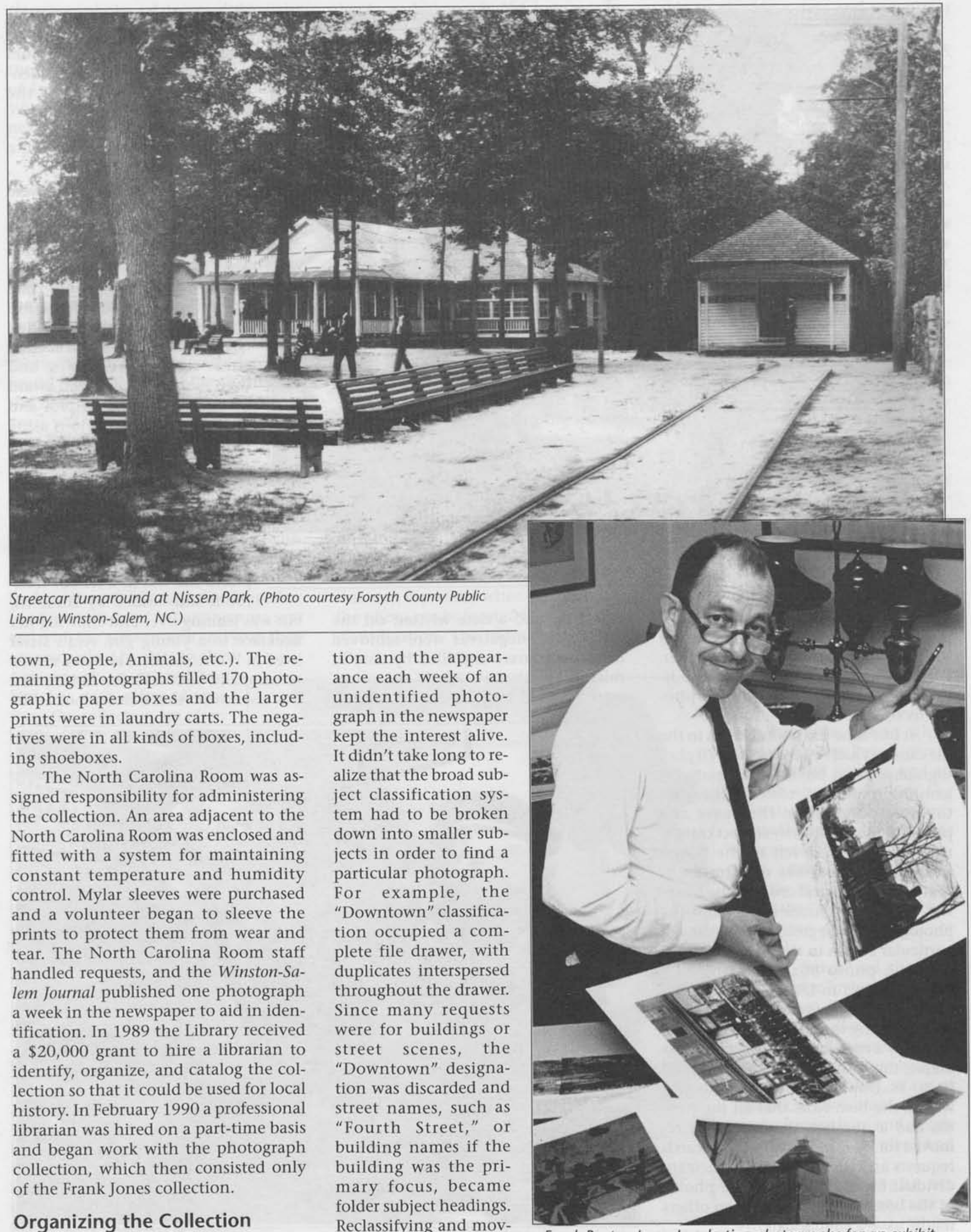

\section{Organizing the Collection}

The Winston-Salem public had long been aware of the photograph collec-

ing 14,000 prints was a time-consuming task,
Frank Buxton Jones Jr. selecting photographs for an exhibit in 1966. 


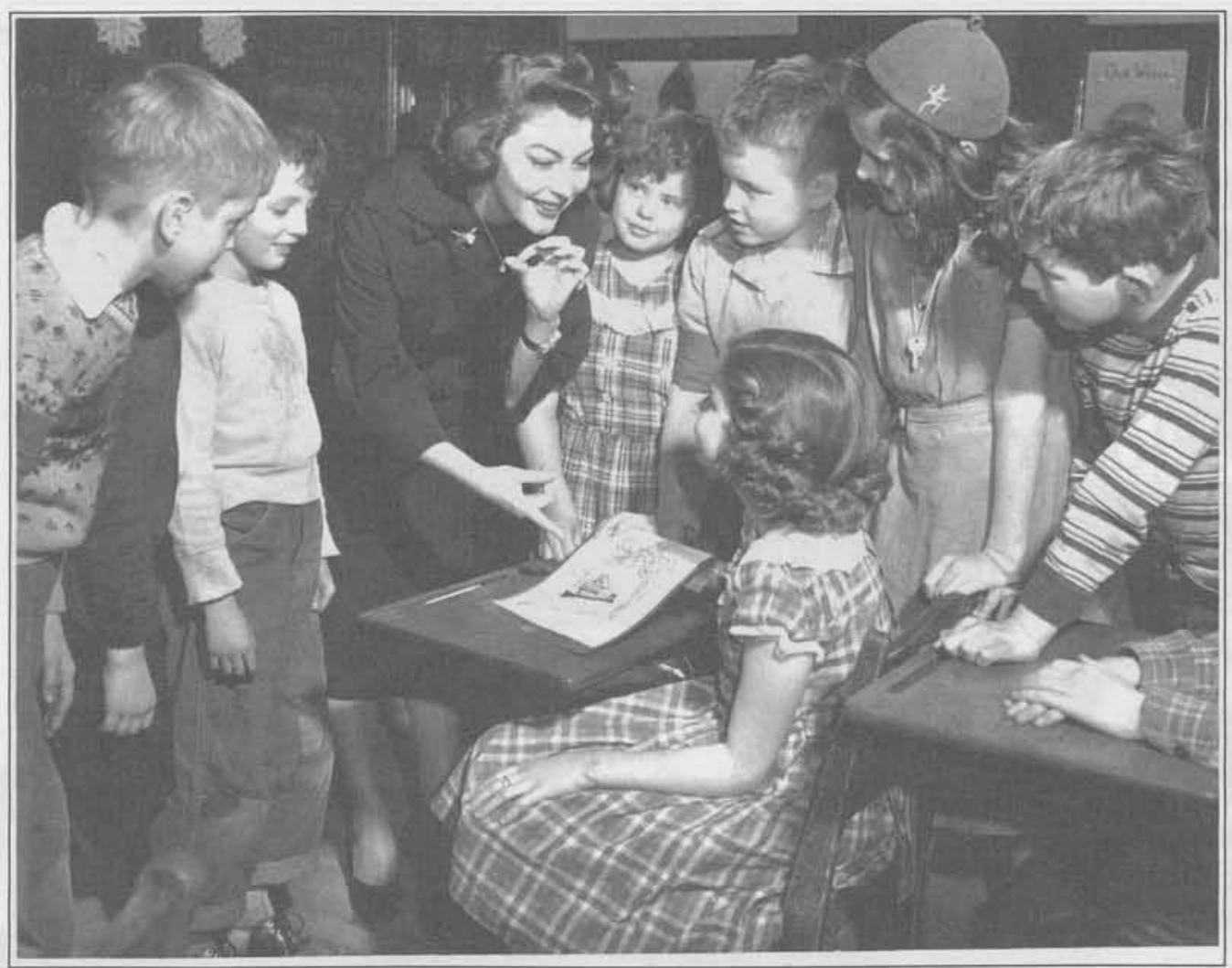

Ava Gardner showing her "Showboat" necklace to niece lean Pierce at Wiley School on January 16, 1951. (Photo courtesy Forsyth County Public Library.)

but the result was a more specific filing system which speeded research time and put the duplicates together. Plus, the entire process made the librarian more familiar with the photos in the file cabinets.

At one time the photographs in the file cabinets had resided in the 170 photographic paper boxes. In an early organization attempt, some of the photos were pulled from the boxes and placed in file cabinets by subject categories. The rest were left in the boxes. Sadly, had the boxes remained untouched, the natural order in the boxes was somewhat chronological and the photographs were grouped according to particular stories in the newspaper.

Each photo box was assigned a number from 1 to 170 . Then, each photograph in the box was assigned a number beginning with the box number followed by a consecutive number. For example, the 18 th photo in box 86 would be $86-18$. Duplicates were also grouped within the box. Now that all the photos had a number, they could be removed for identification or for research requests and then returned to their individual boxes. If some of the photos in the box could be dated, then others might have a similar date.

The negatives were stored in paper negative sleeves which had some iden- tification and a date written on the sleeve. The negatives were removed from their boxes and filed by date in microfilm cabinets. While the prints were in good to excellent condition, many of the negatives were damaged. Still, they could be matched to the prints and would be an important key to the identification and dating of the prints.

\section{Identification of the Collection}

After the boxes and photos were numbered, the librarian went through the photos one by one, noting on the back in soft pencil any information about the photo. Occasionally a photo had names or a date penciled in on the back by the photographer. Clues in the photograph such as street signs, store names, and even names and dates on award certificates, are all helpful and can lead to identifications using library resources such as city directories, local histories, maps, school yearbooks, newspapers on microfilm, and any early booklets published about the city.

One group of photographs featured Ava Gardner. In one photo she was in a school classroom surrounded by students, but was leaning over and showing her necklace to a young girl. Ava's sister lived in Winston-Salem and Ava visited occasionally, but the reason for this visit was unknown. After a closer look at the

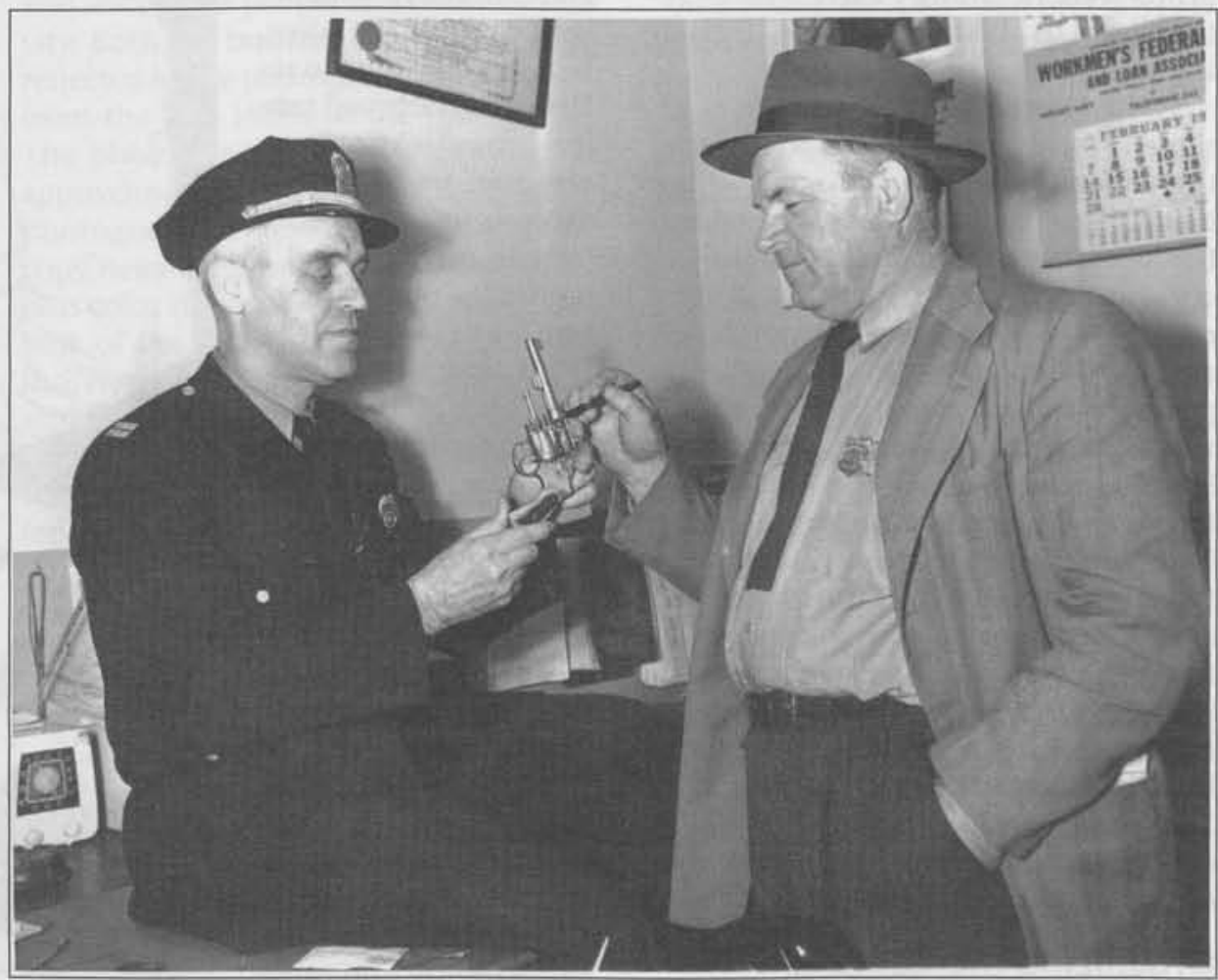

Police Captain W. H. Sumner and Surry County Deputy Roy Smith examine murder case evidence in February 1954. (Photo courtesy Forsyth County Public Library.) 
classroom photo, a date was visible right over Ava's shoulder. The teacher had written the date, January 16,1951 , on the blackboard that morning. The story of Ava's visit to her niece's classroom at Wiley School was in the newspaper the next day. She was showing her necklace, a miniature showboat, to her niece.

Sometimes the photographer will capture a calendar in the photo. Another group of photographs showed that a murder had taken place. In one photo a policeman and a deputy were examining a gun. A calendar could be seen over the detective's shoulder, showing the month as February, but the year could not be seen. Using a perpetual calendar, the years in which the days in February matched this calendar were found. Then, looking at the clothing of the men in the photos, the choice of years was narrowed. By selecting a few possibilities and using the local newspaper on microfilm, the February 1954 article was located which identified the event and the people.

Since many of the photographs were used in the newspaper, those with the same month and year (determined by the negatives or markings on the backs of the prints) are grouped together in a "research box." When there are several with the same month and year, they are researched by date in the newspaper on microfilm. Matches with other photos from the collection are often made during the newspaper search as well. When the article is located in the newspaper, the date and page of the article are written on the back of the photo, along with any other identifying information.

Identification is an ongoing process and volunteers often help in identification. Volunteer workshops are held to enlist volunteer help. Occasionally we are fortunate to find volunteers who have special interests and areas of expertise. A woman who is a Winston-Salem native offered her help in identifying photographs. She looked through many photos in the collection and made many identifications, but she didn't stop there. She often took a group of photos to her bridge club meeting, or a church gathering, and even walked through backyards in search of a gar-

den in a photograph. Her help was invaluable because her circle of friends included women who modeled in the 1940 s when newspapers were filled with society and fashion news.

Another volunteer who has been helping for about eight years actually came with a research request, but later returned to help with identification. The volunteer is a retired insurance salesman, a Winston-Salem native, and is very familiar with the business community. He has assisted on several projects. A recent project involved an identification request from National Geographic Magazine. The Winston-Salem Journal found out about the work for National Geographic and wrote an article about the project and gave some welldeserved recognition to the volunteer.

Unidentified photographs are exhibited in a display case in the library. Each photograph is numbered and anyone who can identify a photo is asked to go to the North Carolina Room desk. At the desk there is a notebook with forms on which they can write the identification, giving the photo number and their name and telephone number. Many photos have been identified in this way, especially when the person in the photo can be located to confirm the identification. The individual is often

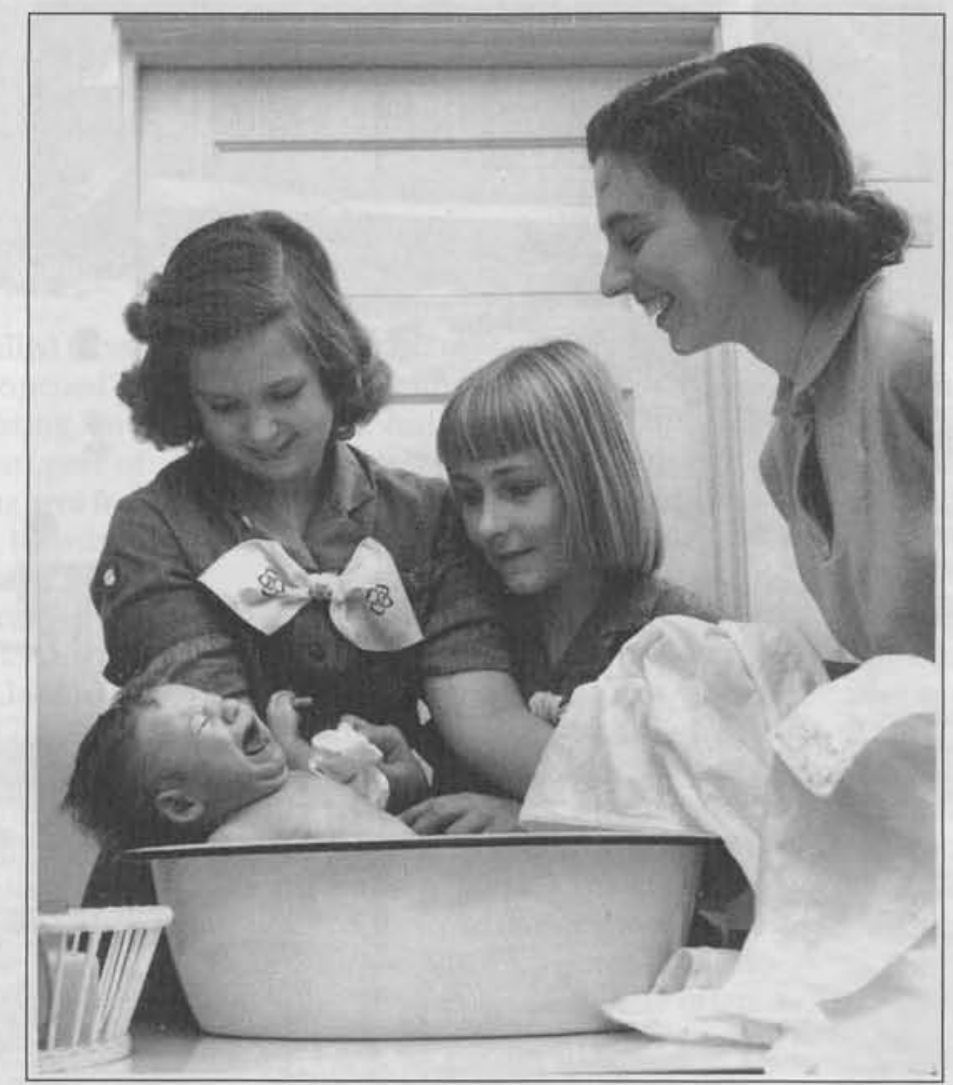

Girl Scouts observe bath procedures for babies under the watchful eye of troop leader Mrs. Gene Robinson in March 1955. able to provide a date and sometimes has a copy of the article as well.

One such identification that came from the display case involved a photograph of a woman demonstrating bathing a baby for a group of Girl Scouts. The woman who identified the photo was actually the wife of the now-grown baby. She didn't recognize the baby, but she did recognize her mother-in-law. When the woman in the photo was contacted, she was able to find the article in her scrapbook. In the photograph she was a Girl Scout leader demonstrating the proper bath procedure as she helped the girls work toward a merit badge.

All identifications have to be verified before they are considered positive. The best method is to locate the individual or someone in the family, or even have several people make the same identification.

\section{Handling Patron Requests}

While the collection was becoming more organized and more identifications were being made, patron requests of the collection became more frequent and complicated. Locating a particular photograph was sometimes difficult even though it was known to be in the collection. The file cabinet was a onedimensional system and did not allow for researching photos by more than one subject.

A database program to index the photos by keyword was being designed when Forsyth County Public Library Director Bill Roberts read an article about a system the Cleveland Public Library was using to index and retrieve its enormous photograph collection. After seeing the system operate in Cleveland, we decided the "Instant Image System" was exactly what we needed.

We purchased the "Instant Image System" in 1991. The system consists of a personal computer with color monitor, a Panasonic videodisk recorder/player, a Sony $13^{\prime \prime}$ color monitor, a video camera, a motorized remote control zoom lens, and a copy stand with cover glass and halogen lights.

The photographs are filmed by the video camera onto a $12^{\prime \prime}$ videodisk, which can record 36,000 images. The images are displayed on 
the monitor and a frame number is automatically assigned to each image. Using a personal computer loaded with the "Instant Image" software and linked to a videodisk player, keywords are assigned to each photograph. There is no practical limit to the number of keywords that can be assigned to each frame number. Once the keywords are assigned, images can be retrieved by typing in a keyword and all images which have been assigned the keyword will be listed on the computer screen. The user can then review the images one after another on the video monitor. An information box can also be viewed on the screen that gives detailed information about the photograph.

The Forsyth County Public Library received a State Library grant to pay for the $\$ 59,000$ system, using matching library funds. Included in this cost was also a patron read-only system that consisted of a personal computer, video monitor and player, and a Sony color printer. The patron station is situated in the North Carolina Room and is accessible at all times the library is open.
There are currently 18,000 images on the system that are indexed by subject and date. In only a matter of minutes a search can be made of the collection for a patron by looking through hundreds of photographs without ever physically touching the original print.

Most requests of our collection are from local residents, for personal or for business purposes. The request usually begins with a telephone call during which the patron states his/her needs. The system can be checked while the patron is on the phone as to whether or not we might have what they need. The photographs that seem to answer their request are described, and if the patron is interested, an appointment is made to view the photographs in question. We also have walk-ins who come to the library with requests.

After meeting with the patron to view the photographs in response to a request, the patron may want to purchase copies of a photograph. We do allow copies to be purchased as long as the photographs are not used for outright personal gain - such as to be sold as prints. A "quick print" can be made at the library or a glossy print can be made at a local photo lab with the library retaining the copy negative for its collection. The patron must pay in advance for the full price of the prints. If copies are to be used in a publication we do require a credit line.

The photograph collection in a public library is unique in that it is considered a special collection. It is one of the few areas where patrons are not allowed to rummage through the materials and have unlimited access. The photographs are treated as archival materials which must be handled properly and that means that patrons cannot search through the original prints. However, with our patron station in the North Carolina Room, the patron does have computer access to the images, which allows us to limit the physical access.

\section{Types of Requests}

There were 80 requests of the collection during 1999 which involved research and having copies made. The majority of requests were from local residents.

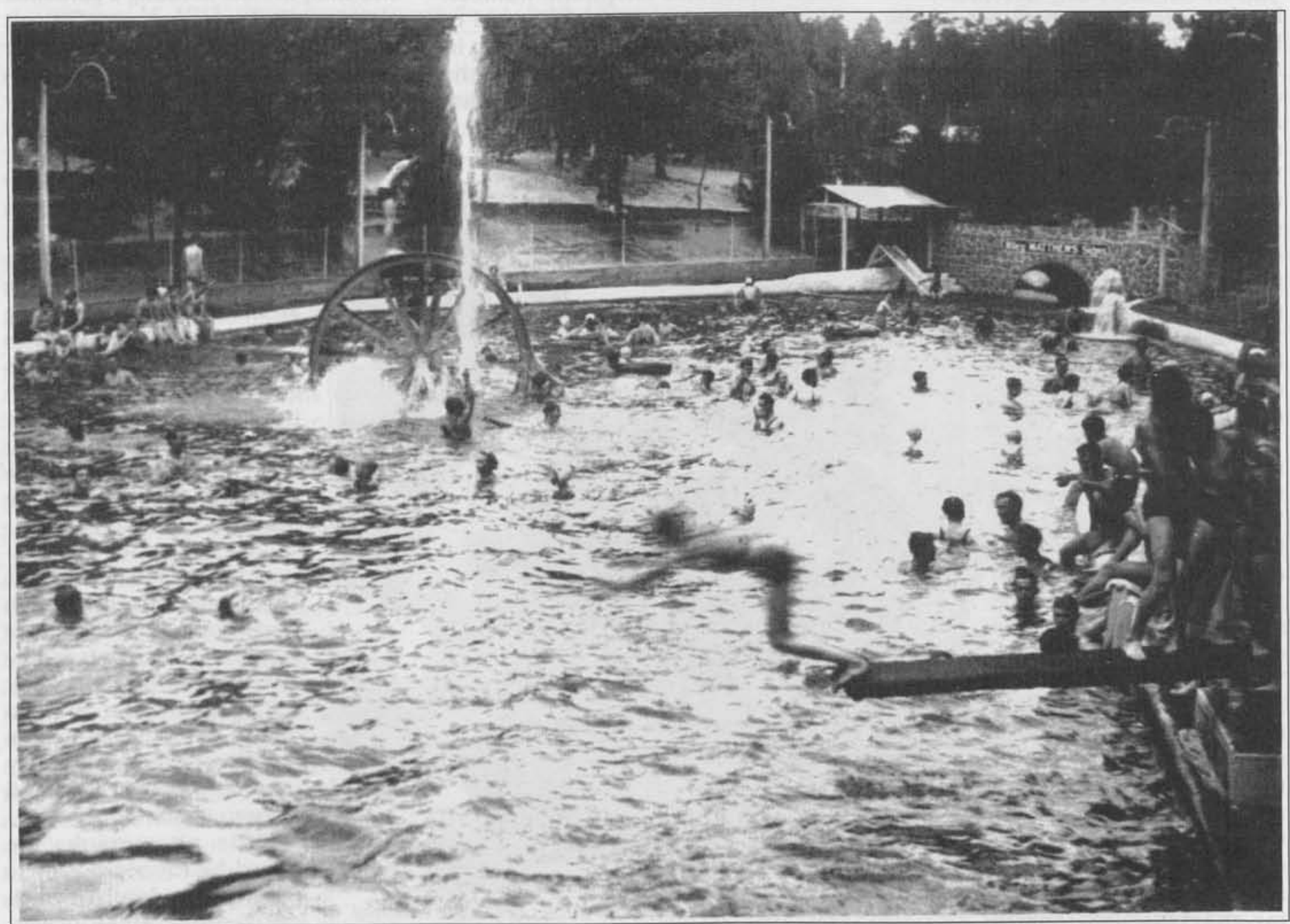

Crystal Lake swimming pool with diving boards, water wheel and fountains. The pool opened in the 1930s. 


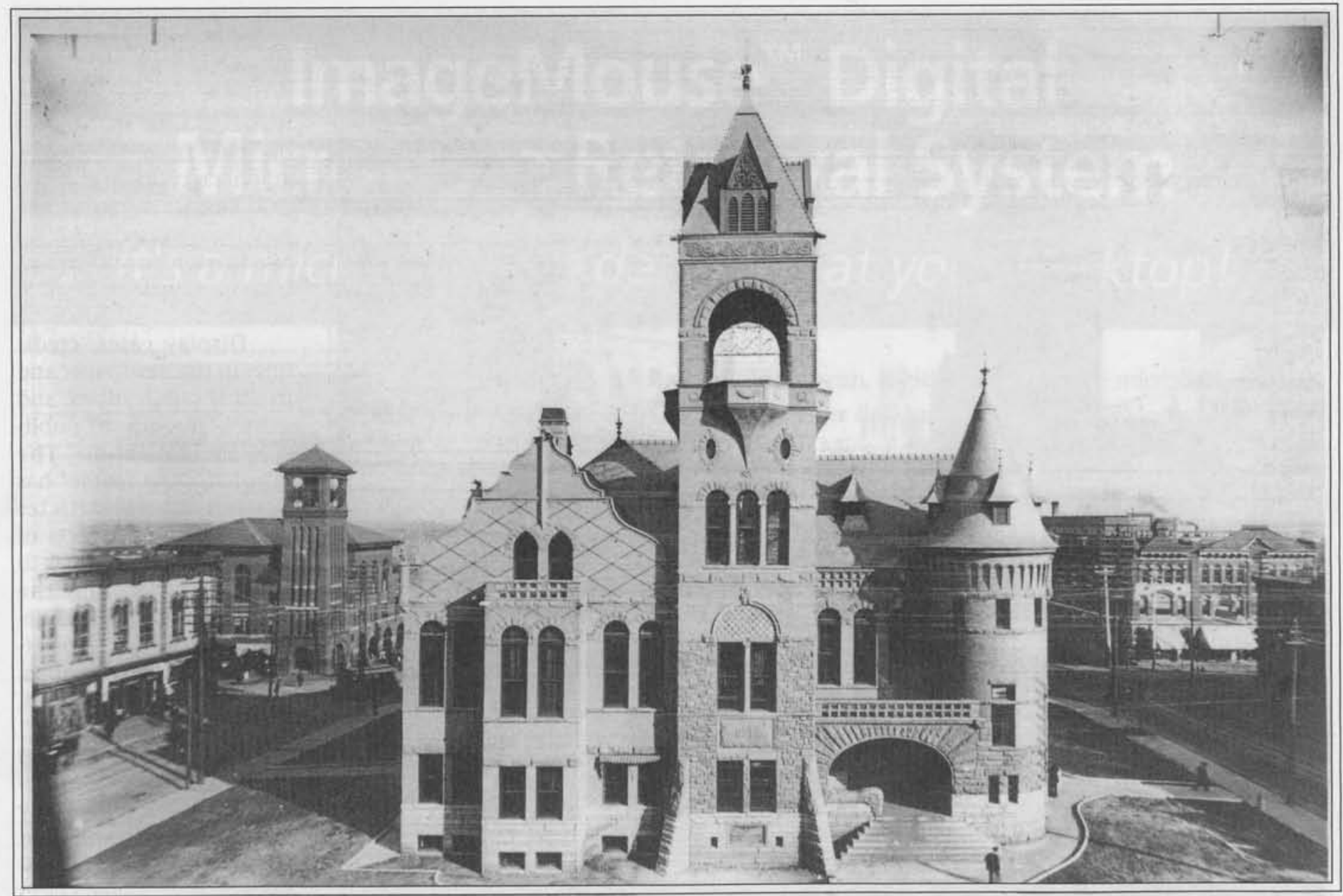

The second Forsyth County Courthouse opened on January 1, 1897.

The personal requests might be for a photograph of a family member, a house, a business, or a place that had special meaning for the patron. We often hear from patrons who want to show their children either a school or recreation area that they frequented when they were young.

One example is a place called Crystal Lake in Winston-Salem. It opened in the 1930 s as a swimming, boating, and recreation area in the northern part of Forsyth County. The swimming area featured several levels of diving boards, a water wheel, and a fountain in the shallow end. A pavilion for dancing overlooked one end of the pool. On the other end of the pool was a lake with canoes for rent and a gazebo on an island. Picnic tables and trees surrounded the entire area. Several generations spent their summer days swimming and socializing at Crystal Lake. In the 1970 s the pool closed and an apartment complex was built on the site. The boating lake and gazebo are still there, but many patrons find that word descriptions fail to do the memories justice. We have many requests for Crystal Lake photos to pass along these memories to later generations.

Downtown restoration has generated many requests in the last few years. Local architects facing restoration projects want to know how a building looked as close to the original construction as possible. By looking at an early photograph, the architect can tell what has been added to the building without having to remove whatever physically covers the building now. This saves money in design and shows potential buyers how the building could be restored to its original look.

Businesses, such as restaurants, often want to use local photographs to decorate their walls. Some want to represent the businesses in town, others want to create a mood, and others want to highlight the city's history. Businesses usually have an interior decorator that is given the task of selecting the photographs, but it could be the restaurant or hotel owner who makes the selection. Depending on the final number of photographs to be selected, this is often a lengthy process that involves several meetings before a decision is made. Other local business patrons are advertising agencies, city and county govern- ment, newspapers, legal firms, and real estate agencies, to name a few.

Occasionally a request comes from out-of-town for photographs of Winston-Salem or local individuals to be used in books, videotape or slide productions, and even television features. We have received requests from CBS News, CNN, national advertising agencies, and National Geographic. If the request is from out-of-town, everything is handled by telephone and the photographs are sent by mail or commercial courier.

\section{Preserving the Collection}

The majority of the photographs are in very good condition. To protect them from daily wear and tear they are encased in mylar sleeves and stored flat in acid-free boxes. The boxes are shelved in a room equipped with humidity and temperature controls. The optimal temperature range for photograph storage is $65-68$ degrees Fahrenheit. The optimal relative humidity range is $45-50$ percent.

The negatives are currently being removed from their regular paper sleeves and placed into acid-free paper 


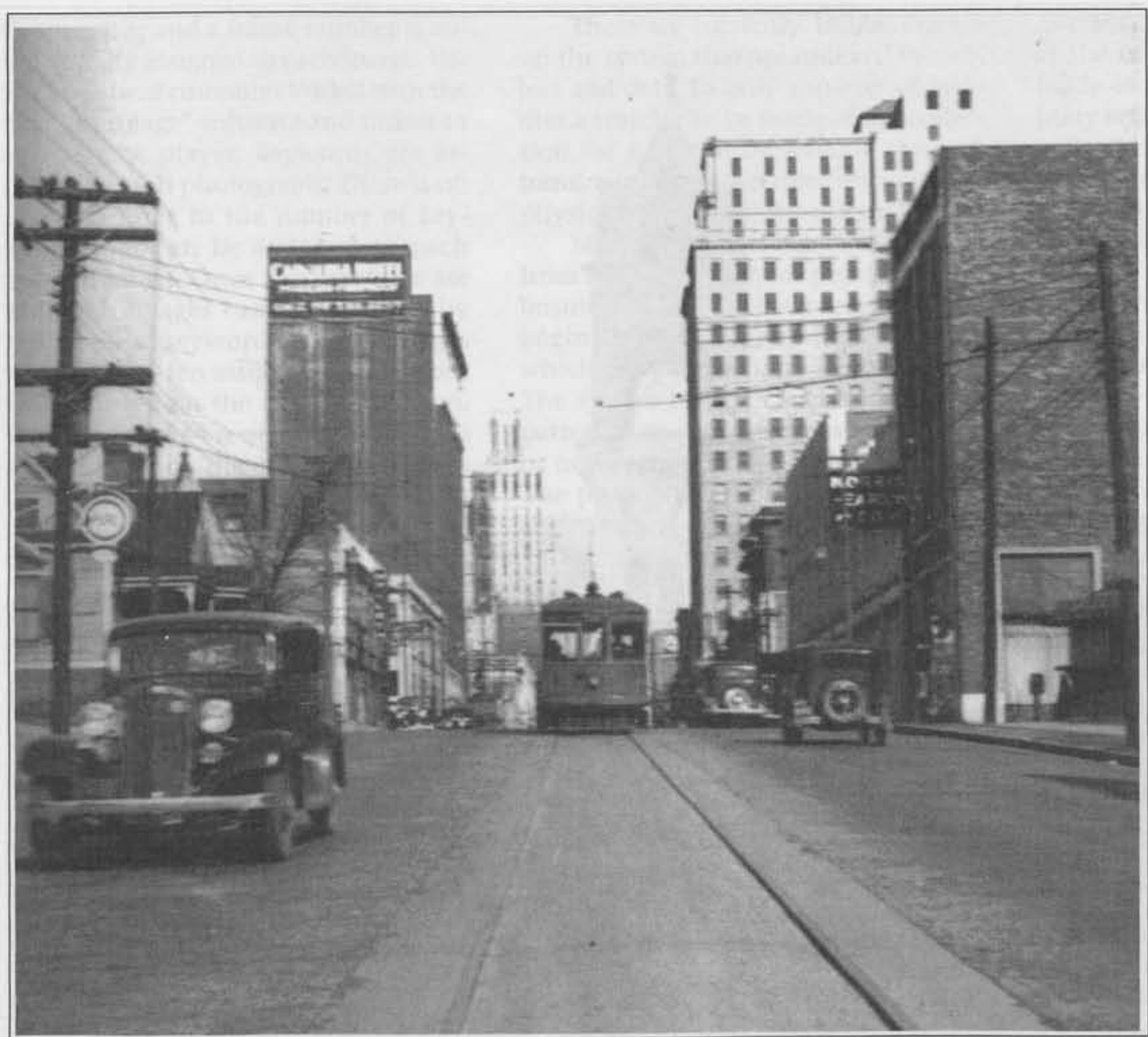

Winston-Salem's West Fourth Street in the early 1930s. (Photo courtesy Forsyth County Public Library, Winston-Salem, NC.)

monitor and transfer the particular images to videotape. At a studio the script is read, recorded, and matched with the images on the tape. A videographer records on tape the "Now" segment in conjunction with the script. Music is added and an historical segment is produced.

Display cases, credit lines in the newspaper and in other publications, and word of mouth all publicize the collection. The Winston-Salem Journal has written several articles about different aspects of the collection. We speak to many groups about the photographs, such as genealogy and historical societies, preservation groups, Boy and Girl Scout groups, and school classes.

Third grade classrooms are frequently visited because the students study local history. Excitement and wonder fill the expressions on the children's faces as they see photographs of the streetcars that once traveled over the cobblestone streets. They are sur-

sleeves. Also, the damaged negatives are separated from the good negatives and stored in a different place. Cotton gloves are worn when handling the negatives and prints to avoid fingerprint and oil damage from hands. Because many of the negatives are damaged and deteriorating, prints are made of as many of these for which we do not have prints as the budget allows. Not having to handle prints during research requests, because of the "Instant Image System," and using copy negatives whenever possible to make copies, are also methods of preservation.

\section{Adding to the Collection}

When the Keith and East photographs were added to the collection, the same procedures for numbering the photographs and encasing them in sleeves were followed. Occasionally we are given photographs to be added to the collection and we are often allowed to borrow and copy photographs to add to the collection. The basic guideline we follow for accepting additions is that the photograph must have local value - that is, the subject must be tied in some way to Forsyth County and it should enhance the collection. If there are restrictions on our being allowed to copy it for patron use, we decline the offer because it would be complicated to have some photographs available to the public while others are not.

\section{Publicizing the Collection}

The purpose of organizing, identifying, and preserving the photograph collection is so it can be seen and enjoyed by the people of Forsyth County. While we consider the collection to be a local treasure, we also take every opportunity to tell residents of its existence. One way in which we publicize the collection is through a segment called "Then and Now" which is part of a monthly "Library Connections" program on a local television station. For "Then and Now" a subject is selected, such as "Forsyth County Courthouses." The subject is researched, then a script is written based on the photographs on the subject. Because the photos are on videodisk, we can hook up a video camera to the prised to learn that the majestic Richard Joshua Reynolds' home once stood where the Forsyth County Headquarters Library is today. And they resolve to notice the clock faces in Calvary Moravian Church that once graced the clock tower of the old Town Hall.

\section{Looking to the Future}

Technological advances give libraries opportunities to reach beyond county and state lines to explore the bounties of other special collections and to share their own. The North Carolina Room staff is investigating ways to make our resources better known to other libraries, genealogists, and historians. The photograph collection is included in our investigation, particularly in the areas of digital storage and Internet access. Also, we are regularly adding to our collection in order to increase our coverage of Winston-Salem/Forsyth County history. Studying history without the visual component would be very dull and dry. Photographs make history come alive! 


\section{ImageMouse ${ }^{\text {Tm }}$ Digital Microfiche Retrieval System \\ It's a microfiche reader right at your desktop!}

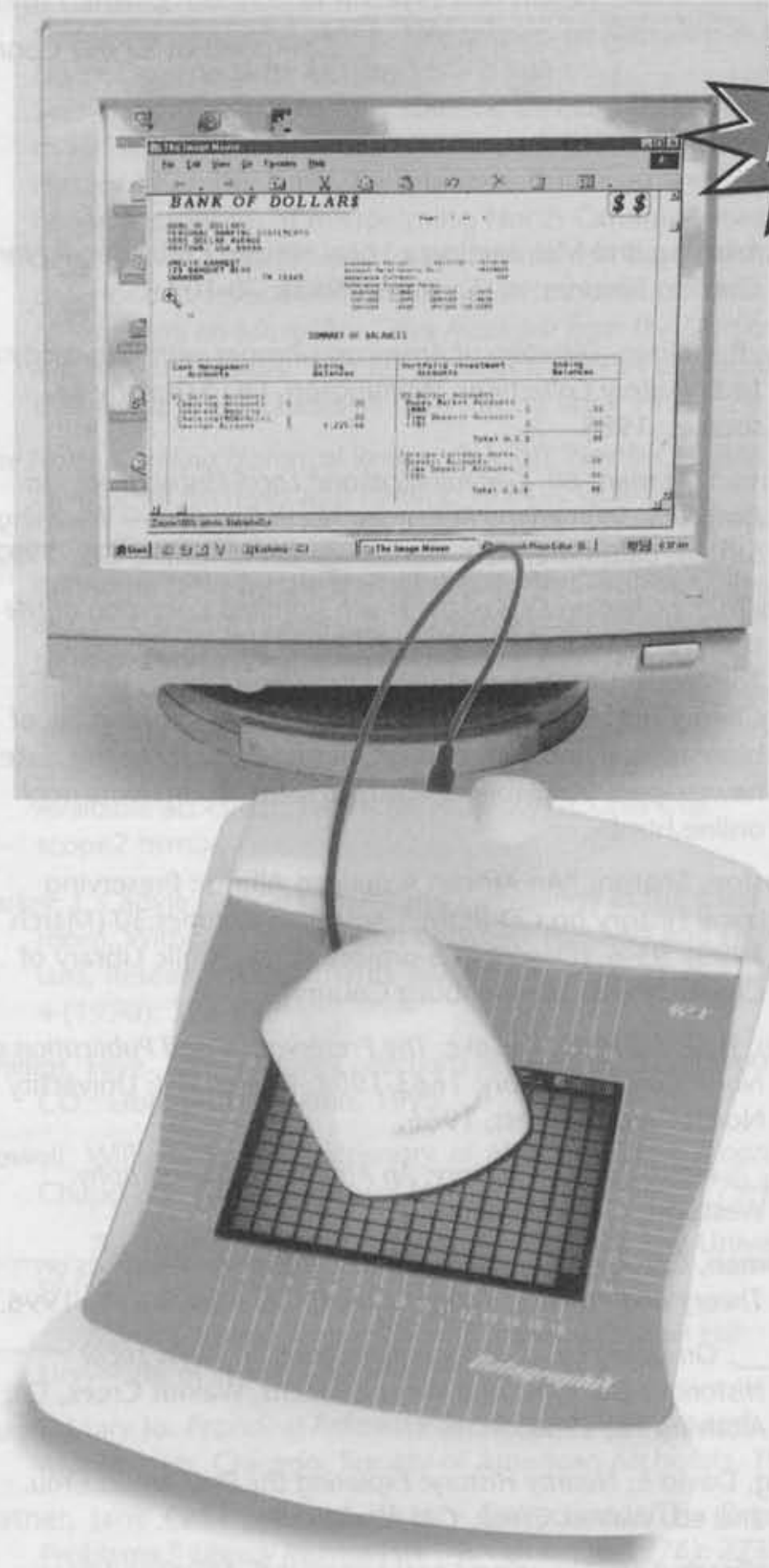

View, scan, digitize and enhance microfiche from your desktop PC! The ImageMouse ${ }^{n t}$ Digital

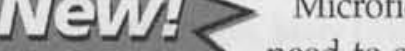
$\checkmark$ need to scan film first before viewing, printing or distributing images. View images instantly as the mouse glides across the microfiche, over its mouse-pad sized, illuminated base.

- Click a key to enhance, store, forward, fax, insert word processing documents or e-mail images.

- Easy to use software is compatible with all popular Windows programs.

- Views negative and positive microfiche.

- Automatically zooms in to see text larger in search mode or zooms out to capture full-sized page images.

- Crop, rotate and enhance images before printing.

- Small, mouse-pad sized base fits any workstation.

- Symmetrical design for left-or right-hand use.

- Digital quality prints from any Windows compatible printer.

Minimum PC requirements: CPU: Intel Pentium Class II or III, $400 \mathrm{Mhz}$ or better; RAM: $64 \mathrm{MB}$; Video RAM: $8 \mathrm{MB}$ or better; HDD 50 MB (Free space); USB Support, 110V$240 \mathrm{~V}, 50 / 60 \mathrm{~Hz}$; Monitor: $800 \mathrm{H}$ x $600 \mathrm{~V}$ dot; Operating System: Microsoft" Windows '98 2nd Edition/NT (Summer 2000): Intel chipset for PCI to USB controller; Printer: Windows compatible. $(1 \mathrm{lb}$.) Ships from manufacturer.

\section{Cat.\# Description}

$84390001 \quad 42 X$ and 48X Reduction Model

$8439000224 X$ and 28X Reduction Model
Price

$\$ 1,215.00$

$1,359.00$ 